\title{
Biography of Are Tsirk (1937-2015): Flintknapper and scholar
}

\author{
Steve Adams \\ Independent researcher. 468 Summit Ave, Hackensack, NJ 07601, USA. Email: protosteve@aol.com
}

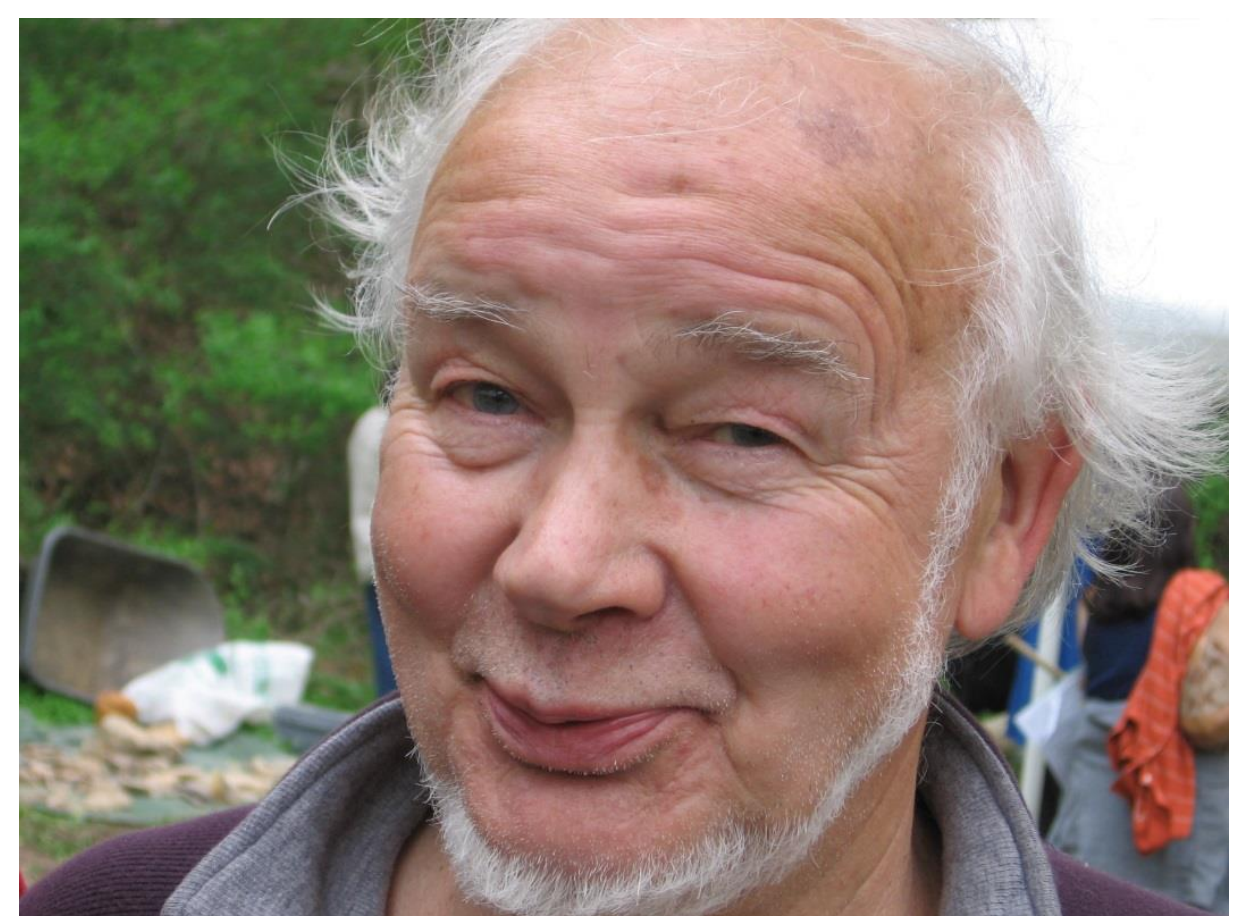

Are Tsirk in 2008, at the Primitive Technology Weekend, Oregon Ridge Nature Center, MD, USA. (Photo by Ming Diaz.)

Are Tsirk was as much a scholar as he was a flintknapper. These disciplines were intertwined and expressed in his experimental research, by way of his exploration of fractography, and his replication of stone tools which spanned the archaeological record of several continents.

He was born in 1937 in Tallinn, Estonia. As the Soviet Union brutally occupied this small Baltic country in September 1944, his family fled by boat to the West, living as war refugees in a DP (Displaced Persons) Camp in the American Zone of Germany, until they emigrated to the United States in 1951.

As a young man, his athletic ability was exercised in competitive swimming as the Captain of the New York University team in the late 1950's. He was also an avid recreational

Published by the School of History, Classics and Archaeology, University of Edinburgh ISSN: 2055-0472. URL: http://journals.ed.ac.uk/lithicstudies/

This work is licensed under a Creative Commons Attribution 2.5 UK: Scotland License. 
downhill skier and ski jumper, and participated in other robust activities. It was while he was a student that he met his future wife Epp (also from Estonia) whom he married in 1963. After serving in the early 1960's in the U.S. Army Corps of Engineering in Arizona and Okinawa, Are earned all of his academic degrees, BCE (1959), MCE (1964), PhD (1968) in Civil (Structural) Engineering at NYU.

In 1968, purely by chance, he read Francois Bordes' seminal volume "The Old Stone Age" (Bordes 1968) and became enthralled with prehistory, especially stone tool manufacture and fracture analysis. In a small Manhattan apartment he used a toothbrush handle to pressure flake industrial glass which he procured by following fire trucks to burned-out storefronts. The strength of this fascination led him to Don Crabtree's flintworking field school in 1973 and the Idaho workshops addressing the intricacies of knapping technologies became invaluable experiences. He enrolled once again at NYU but this time in the Department of Anthropology. Are received his MA in Anthropology in 1974, completed all of the required course work and exams for a Doctoral degree but in the end did not complete his dissertation for sheer lack of available time. Over the span of decades after, Are would relate lessons he had learned and impressive feats of knapping skill performed by his renowned early mentor to both his fellow knappers and beginners alike. The anecdotes of his observations and experiences as a student of Don Crabtree provided unique first-hand insights into the master's teaching style and skill; Crabtree encouraged Are toward presenting, recommending him for demonstrations and lectures. Later in life he would reference his ongoing studies relating fractography to flintknapping as an outgrowth of this period, a response to Crabtree's suggestion that he pursue the finer points of a shared curiosity. When he published his 2010 paper titled "Popouts and Related Fractures" (Tsirk 2010), his concluding acknowledgements began by stating "This article is a belated response to the inquiries by Don Crabtree, in 1973, and Jaques Tixier, in 1975, on popouts. I am grateful to them for the stimulating inquiries. For any merits of the study, they deserve the credit."

Another trusted mentor was Ralph Solecki, most widely known for his illuminating Mousterian excavations at Shanidar Cave in Iraq between 1957 and 1961. Reflecting on Are's analytical insights, he commented that due to circumstances of timing, "Are did not participate in my local or Near East work - although I do regret that I did not meet him sooner. He would have been a tremendous asset to our investigations." (personal correspondence with Ralph Solecki in 2015). Ralph and his wife Rose Solecki maintained an abiding friendship with Are throughout the remainder of his life.

Are's passion for stone tools was boundless as was his enthusiasm and persistent analysis of fractures and fracture markings. His advanced education in engineering and anthropology, formal training and experience in archaeology, and a legacy of extensive knapping provided a strong background particularly outfitting him for his unique research. This is reflected in his numerous publications on fracture mechanics, fractography, and lithic technology, and his membership in both the Society of American Archaeology (until 2011) and the Society of Primitive Technology (until 2013), as well as being a Fellow of The American Society of Civil Engineers. In his capacity as a civil engineer, Are formed an independent engineering and consultant firm. Among his efforts in design and research his tasks included:

- Development of methodologies, design and testing of missile silos for blast effects;

- Investigation of failure and distress of structures, including brittle fractures;

- Research on seismic isolation and vibration of structures; and

- Teaching graduate courses on structural analysis and design of structures, including structural dynamics, seismic effects and finite element methods. He held positions as an Associate of Weidlinger Associates, Associate Professor at the New Jersey Institute of Technology, and was the Principle Research Engineer for the Metropolitan Transportation Authority of New York. 
In reference to his professional activities related to lithics he was a fractography consultant, with reports given to A. Steffen, W. Parry, P. Kelterborn, E. Callahan, J. Pelegrin, J. Tixier and others. In the 1970s he participated in over fifteen archaeological excavations, and analysis of the J. R. Coates collection of over 12,000 lithic specimens at the Heye Foundation. He was also a long-term consultant with V. D. Frechette, S. W. Freiman and H. G. Richter on fractures. His contributions drew from a unique professional perspective which evolved from a personal interest in flintknapping; through the course of over forty years of practice he offered demonstrations at:

- Archaeological Societies of New York, Illinois and Maine;

- Montclair State University of NJ in association with Peter Siegel, and many other local universities including NYU, Hunter College, Adelphi University, and The New School;

- The nationally and historically significant Estonian University of Tartu, and two additional universities in Estonia, the University of Science and Technology and the University of Archaeology and Anthropology, both in his native Tallinn;

- Grimes Graves Flint Mine, Brandon, UK with John Lord (1980);

- First International Conference on Fractography of Glasses and Ceramics, and Alfred University (1986); and

He also taught flintknapping at the University of Maine (1974), University of Tartu (2004 and 2010) and Montclair State University (2011). A sample of his teaching method may be discerned in his lecture notes from the 1997 presentations at Tartu University in Estonia titled "On Flintknapping" (Tsirk 1997). It is reasonably sequenced and well organized, covering topics introducing the subject, the history of knapping, knapping studies, raw materials, knapping tools, basic techniques and principles. From this substantial foundation he proceeds next to introduce fractography, followed by an exploration of how this science relates to knapping. There is a sprinkling of mathematic equations, and many microphotographs and drawings illustrating the finer details of his discussions, providing a clear and cohesive entry of the topic to his larger subject. He concludes with explanations of the process of learning to knap, followed by a couple of appendices which include an extensive recommended reading list. Are identified the study of fractography as an obvious component of flintknapping as clearly as he saw fracture markings on blades and flakes, and this is reflected in the unified manner of presentation offered to his university students in Tartu. The material is uniformly rich and at times references the empirical evidence borne of his research and experimentation, as well as ample in-class material samples and knapping demonstrations.

The relationship he saw between fractography and knapped stone offered an analytic tool of potential utility. In his Tartu lecture notes he observed that "To make use of mechanics in flintknapping, the key is to recognize what these elements are and what the field of mechanics can do.... Application of mechanics can pose questions and point to relevant data not apparent otherwise." (Tsirk 1997). To the flintknapper and lithic analyst, the vision of fractured stone Are described illuminates the nature of instantaneous force delivery. Flakes, blades, and cores disclose finely detailed information through subtle yet distinct markings which give the passage of energy a permanently identifiable character.

He perceived merit in the ability of fracture markings to identify force direction, fracture velocity, core to blade geometry, artifact breakage (whether during manufacture or after, from usage or post-depositional accident), and more. An assessment of such features could provide a more precise means of analysis and additional depth to functional studies. From obsidian flakes and blades he examined microscopic evidence of liquid-induced fracture, and experimented flaking with water, saliva, blood, and honey to verify the characteristic markings associated with liquid media of varied viscosities (even knapping with both pressure and percussion underwater). These experiments suggested that "a significantly smaller force" 
is required to promote fracture when the stone is wet, a factor pertinent to enhancing control within the variable dynamics of flintknapping (Tsirk 1997). Although he had notions of how his applications could avail interpretive tools to lithic analysis he invited others to engage them for their own research questions and hypotheses.

Professor George D. Quinn is a specialist in ceramic materials, an engineer, fractographer and material scientist; nearly all of his work has been with modern high tech ceramics and glasses. He is also the author of the book "NIST Recommended Practice Guide: Fractography of Ceramics and Glasses" (2006), and a researcher at the National Institute of Standards and Technology, Gaithersburg, MD. On the topic of Are's contributions, he has offered the following thoughts:

Are helped bridge the high tech ceramics and lithic communities. Many researchers in the high tech ceramics and glass field were unaware of the insightful work on lithics that could be applied to modern materials. As a result of Are's suggestions, over the years we invited some well-known lithics fractographers such as Terry Engelder, Brian Kulander, and Otto Muller, to participate in the quadrennial Fractography of Ceramics and Glasses conference series organized by Alfred University. This culminated at the end of the July 2006 conference, when Professor Engelder led a memorable and inspirational field trip of the Devonian Catskill Delta Complex in the vicinity of Corning, Watkins Glen, and Ithaca, New York. Note [the] photo. The bridge shows Are next to Engelder, who unfortunately has his back to the camera.

The bridge is an apt metaphor here. Engelder and Tsirk were bridging the high technology ceramics and lithics communities. Are contributed to these conferences with some fascinating presentations on liquid induced fracture markings. Are's book will reinforce this bridge and be a valuable aid in the future to both the lithic and engineering ceramic communities.

Are's enthusiasm was on display when he brought some of his collection to these conferences and put on live knapping demonstrations for the attendees. These were not only entertaining, but very informative.

As an example of Are's influence on the high tech ceramic community, he alerted us to prior lithic research on 'edge chipping' methodologies and analyses. Edge chipping is a common problem with engineered ceramic component fractures. Edge chipping is also a leading cause for ceramic and composite dental restoration (bridges and crowns) fractures. Test methods and analyses are being devised by the engineering and dental communities to evaluate a material's chipping resistance. Are pointed us to the wealth of experience and prior art in the lithic community that provided great insights to workers studying other materials.

I am in the process of preparing the second edition of my book "Fractography of Ceramics and Glasses", and it shall include some important scarp, wake hackle, and gull wing images that Are kindly furnished to the author. I am grateful for his enthusiasm and help to our field.

George Quinn

NIST

(Personal correspondence with George Quinn in 2015) 


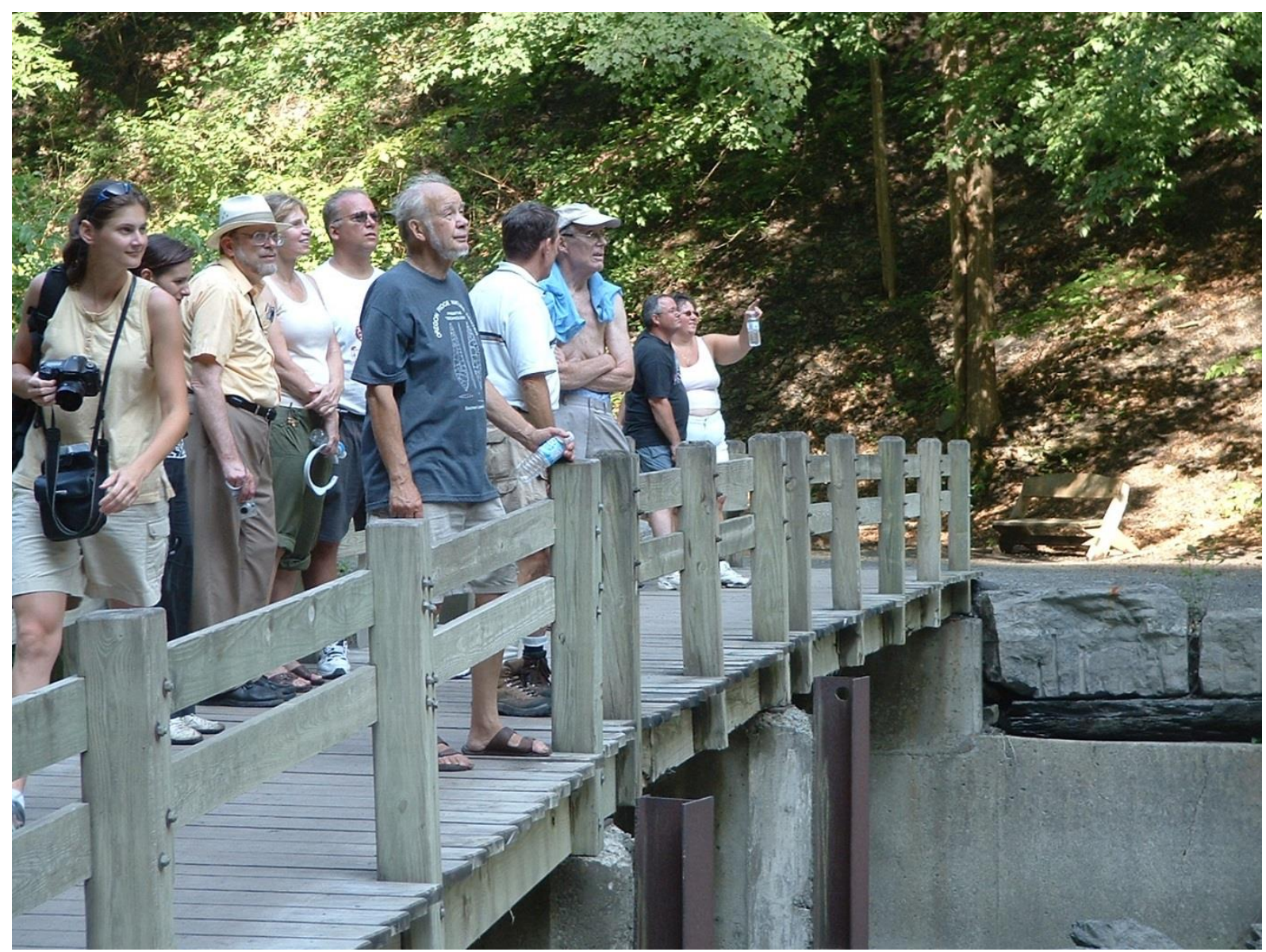

Figure 1. Are Tsirk and Terry Engelder in 2006 at the Devonian Catskill Delta Complex in the vicinity of Corning, Watkins Glen, and Ithaca, New York. (Photo by George Quinn.)

Beyond the discipline of research, his familiarity with fracture markings in stone exceeded the limits of the microscope, commenting in his 1997 Tartu lecture notes that, "... markings, especially the finer ones, depend on grain size. Some markings not seen on a small chert flake may be observed on cliffs of even coarser sandstone, for example." (Tsirk 1997).

Any biography is a terse summary of an expansive life studded with notable achievements and distinctive qualities necessarily selected from outstanding characteristics, often at the expense of those which best exemplify the subject's individuality and vitality. Are Tsirk's influence and legacy are tantamount to the significance of his work as a scholar and teacher. His enthusiasm and passion was embedded among his greatest contributions, an ability to cultivate growth. He was eminently approachable and amiably expressed himself with a sense of humor and wit. At gatherings, events, and flintknapping convocations he would often be seen working on square-section axes, punching blades from a core or simply bifacing, always welcoming inquiries with simple honesty and a desire to share. He was widely recognized among his friends and those whom he influenced in the lithic community as a kindred flintknapper and rock chaser.

During his last several years, he decided that over four decades of flintknapping and research needed to be distilled into a presentable summary of his findings and observations. This included a re-examination of many thousands of fracture samples which he had knapped and curated, a daunting task in itself. The resulting text representing his life's work was published by Archaeopress Ltd. in Oxford in 2014, and titled "Fractures in Knapping" (Tsirk 2014). In referring to this final work, Ralph Solecki has remarked, "I believe the book Are 
wrote is the best authoritative writing on the subject." (personal correspondence with Ralph Solecki in 2015). And long-time consultant and colleague in lithic pursuits Scott Silsby considers that, "in the history of flintknapping Are is likely the first and only person to have achieved a commanding expertise in the craft while also mastering the principles of modern engineering. As a polymath he grasped the knapper's practice of causing and controlling fractures in stone, while his study of fractography, a discipline of studying failures in similar materials, derived from both processes. Are's book documents a convergence of the intuitive and empirical where lithic studies engage fracture mechanics. Without doubt, it will become a required text in institutions of advanced learning as it embodies the highest order of understanding exploring the relation between these subjects. The glossary he wrote codifies a scientific language of concise terms which render accessible a unified dialog between the lithic community and fractographers to facilitate a precise, mutually beneficial exchange. This contribution holds promise for the on-going study of these disciplines and represents just a fraction of his legacy." (Personal communications with Scott Silsby in 2015).
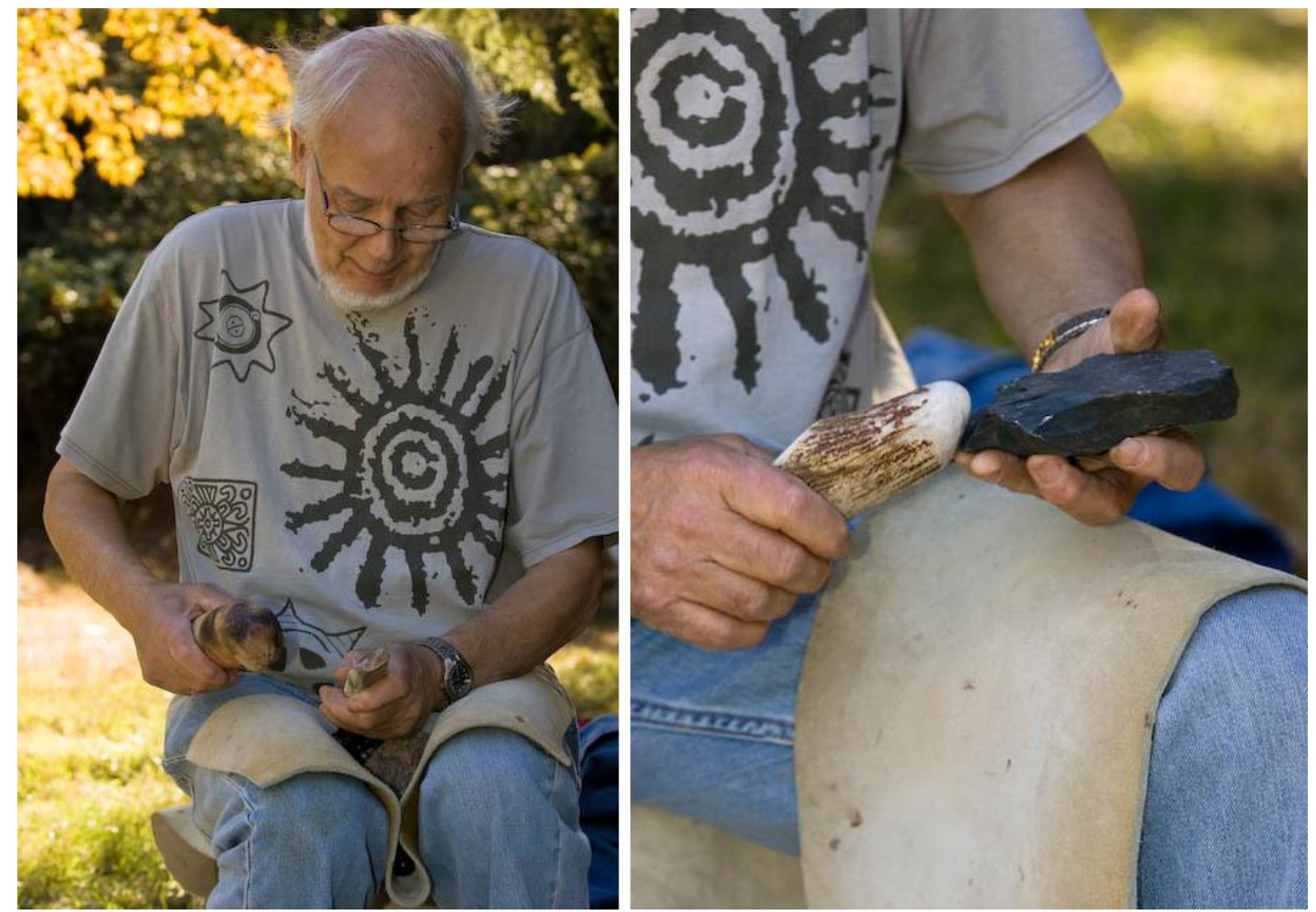

Figure 2. Are punching blades (left) and bifacing (right) in 2007 at the Experimental Archaeology Weekend, Washington's Crossing State Park, NJ, USA. (Photos by Jack Rabin.)

It was not long after he received the first copy of his book, with great satisfaction, that he died after a valiant struggle with cancer, at home with his wife Epp in Upper Montclair NJ, USA on February 17, 2015. Are Tsirk leaves behind very many whom he inspired, educated, and motivated through his erudition, companionship, kindness and generosity. His distinguished bearing and sense of dignity were complemented by his genuine humility and authenticity. 


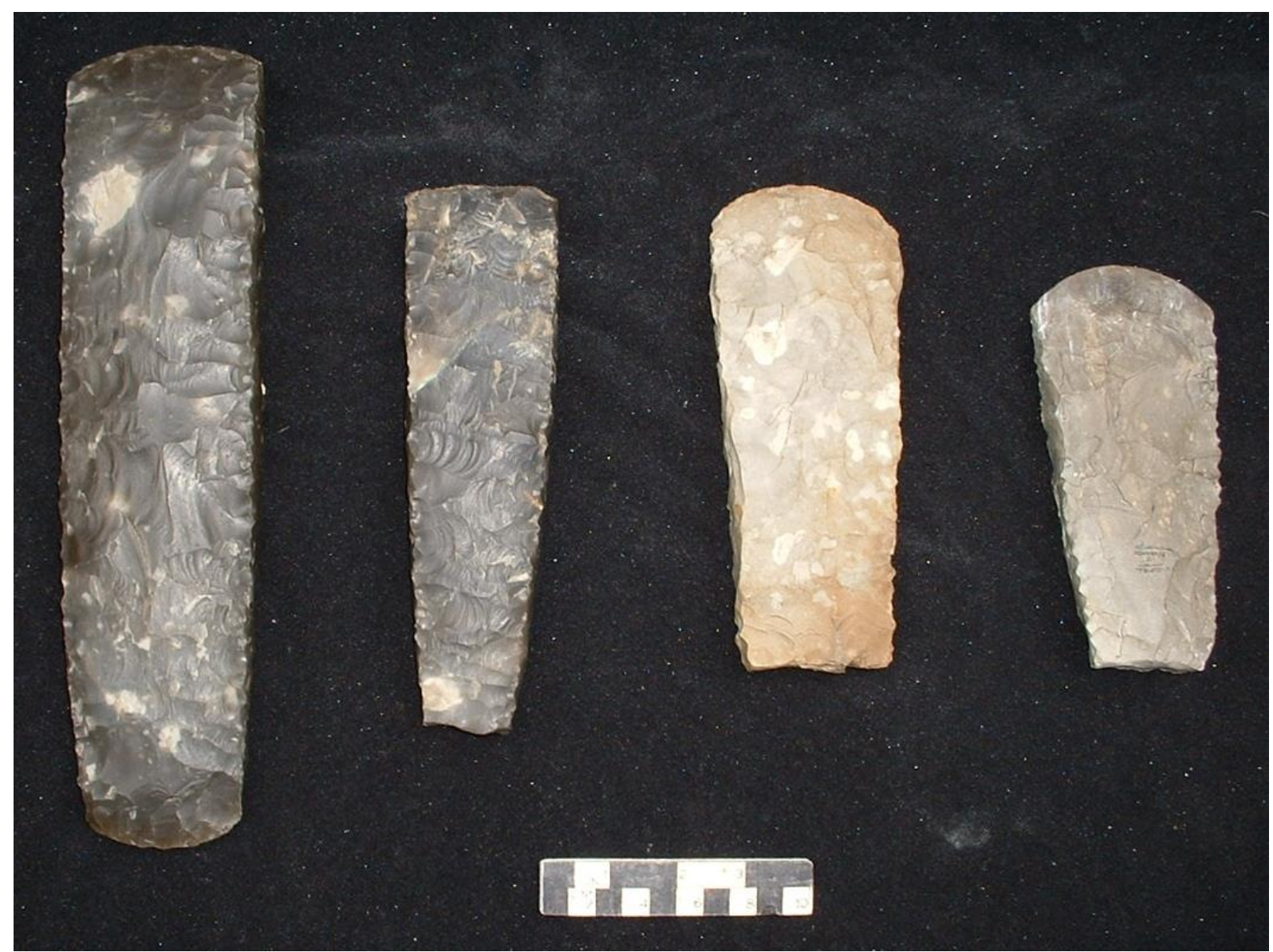

Figure 3. A sampling of Are's square-section axe work. (Photo by Jack Cresson.)

\section{Bibliography}

\section{Publications (by year):}

Tsirk, A. 1979, Regarding fracture initiations. In: Lithic use-wear analysis (Hayden, B., Ed.) Studies in Archaeology, Academic Press, New York: p. 83-96.

Tsirk, A. 1981, On a geometrical effect on crack front configuration. International Journal of Fracture, 17(6): R185-R188. (in English) doi:10.1007/BF00681566

Tsirk, A. 1988, Formation and utility of a class of anomalous wallner lines on obsidian. In: Fractography of glasses and ceramics (Frechette, V.D. \& Varner, J.R., Eds.) Advances in ceramics Vol. 22, American Ceramic Society, Westerville, Ohio: p. 57-69.

Tsirk, A. 1989, On flaw characteristics, environmental factors and fracture markings related to obsidian flaking. In: La Obsidiana en Mesoamérica (Gaxiola, M. \& Clark, J.E., Eds.) Serie Arqueología; Colección Científica Vol. 178 Vol. 176, Instituto Nacional de Antropología e Historia (Mexico), Mexico City: p. 137-146.

Tsirk, A. 1995, Hackles revisited. In: Fractography of glasses and ceramics III Vol. 64 (Varner, J.R. \& Frechette, V.D., Eds.) Ceramic Transactions Vol. 64, American Ceramic Society, Westerville, Ohio: p. 447-472.

Tsirk, A. 1998, Kivitootlemine Lohestustehnikas. Ajalooline Ajakiri. The Estonian Historical Journal, 4(103): 5-14. (in Estonian) ("Percussion stoneworking") 
Tsirk, A. \& Parry, W.J. 2000, Fractographic evidence for liquid on obsidian tools. Journal of Archaeological Science, 27(11): 987-991. doi:10.1006/jasc.1999.0508

Tsirk, A. 2001, An exploration of liquid-induced fracture markings. In: Fractography of glasses and ceramics IV (Varner, J.R. \& D. Quinn, G., Eds.) Ceramic Transactions Vol. 122, American Ceramic Society, Westerville, Ohio: p. 87-104.

Tsirk, A. 2005, Obsidian fractures from a forest fire zone in Santa Fe National Forest (Report No. 020607). In: The Dome Fire obsidian study: Investigationg the interaction of heat, hydration, and glass geochemistry (Steffen, A., Ed.) Ph.D. Thesis, Department of Anthropology, University of New Mexico, Albuquerque, New Mexico: p. 278-325.

Tsirk, A. 2007, Liquid-induced fracture markings: An overview. In: Fractography of glasses and ceramics V (Varner, J.R., Quinn, G.D. \& Wightman, M., Eds.) Ceramic Transactions Vol. 199, Wiley-Interscience, Hoboken: p. 79-91. doi:10.1002/9781118144152.ch8

Tsirk, A. 2009a, A Knapping Dilemma with Transverse Blade Breakage. Lithic Technology, 34(2): 111-118.

Tsirk, A. 2009b, Notes on a Fractography Guide. Lithic Technology, 34(1): 3-6.

Tsirk, A. 2010a, Fracture markings from flake splitting. Journal of Archaeological Science, 37(8): 2061-2065. doi:10.1016/j.jas.2010.03.011

Tsirk, A. 2010b, Popouts and Related Fractures. Lithic Technology, 35(2): 1049-1070.

Tsirk, A. 2012, Fractography lessons from knapping. In: Fractography of glasses and ceramics VI (Varner, J.R. \& Wightman, M., Eds.) Ceramic Transactions Vol. 230, Wiley, Hoboken: p. 123-132. doi:10.1002/9781118433010.ch9

Tsirk, A. 2014, Fractures in knapping. Archaeopress, Oxford, 261 p.

\section{Presentations and Reports:}

1974 “Continuum Mechanics and Flaking: Some Comments and Questions”, Symposium on Primitive Technology and Art, University of Calgary.

1974 "Mechanics and the Study of Prehistoric Stone Tools", NY Academy of Science (Joint Anthropology and Engineering Sections).

1986 "Fractography in Flintworking: An illustrated discussion of the formation and utility of fracture markings on obsidian", Columbia University.

1996 "Fractures in Knapping”, Columbia University.

1997 “On Flintknapping”, Report and lecture notes on presentations at University of Tartu. March 1997.

2002 "Fractographic Evidence for Liquid on Aztec Blades from Otumba: An Exploratory Investigation", Report No.020213, February 20, 2002.

2003 "Liquid-Induced Fracture Markings (LIFMs): Examples and Notes", For use in a course on Fracture Analysis of Glasses and Ceramics at Alfred University, October 15, 2003.

2012 "Knapping Lessons from Fractography Using Normanskill Chert”, 96th Annual Conference of the New York State Archaeological Association, April 27-29, 2012. Abstracts volume, p. 15-16. 


\section{Additional references cited in the text}

Bordes, F. 1968, The Old Stone Age. World University Library. McGraw-Hill, New York, $255 \mathrm{p}$.

Quinn, G.D. 2007, NIST Recommended practice guide: Fractography of ceramics and glasses. NIST Special Publication 960-16. National Institute of Standards and Technology, Washington, D.C., 546 p. URL: http://www.nist.gov/manuscriptpublication-search.cfm?pub_id=850928 